\title{
Impact of Incubated Enterprises' Cognitive Social Capital on Innovation Performance in Incubation Network: Acting through Intangible Resources Acquisition
}

\author{
Zhenhua Li, Fuwei Li \\ College of Management and Economics, Tianjin University, Tianjin, China \\ Email: li_zhh2004@126.com,1fw1008@163.com
}

How to cite this paper: $\mathrm{Li}, \mathrm{Z} . \mathrm{H}$. and $\mathrm{Li}$, F.W. (2017) Impact of Incubated Enterprises' Cognitive Social Capital on Innovation Performance in Incubation Network: Acting through Intangible Resources Acquisition. Open Journal of Social Sciences, 5, 74-83.

https://doi.org/10.4236/jss.2017.510007

Received: July 25, 2017

Accepted: October 10, 2017

Published: October 13, 2017

\begin{abstract}
In the background of incubation network, the paper studies how incubated enterprises gain cognitive social capital through embedding in the network, obtain intangible resources effectively in the resource-sharing environment and improve their innovation performance. We construct and analyze the theoretical model of cognitive social capital, intangible resource acquisition and innovation performance. The incubated enterprises need to strengthen cognitive social capital accumulation through incubation network; it effects the ability of intangible resource acquisition, then helps start-ups improve innovation performance.
\end{abstract}

\section{Keywords}

Incubation Network, Cognitive Social Capital, Innovation Performance, Intangible Resource Acquisition

\section{Introduction}

With the development of new round industrial revolution, especially the rapid growth of the Internet innovation, "mass entrepreneurship and innovation" is promoted to the new height as one of the "double engines", which gives impetus to the economy transformation and guarantees the economy growth. As a bridge between source of knowledge innovation and high-biotechnological industries, meanwhile the platform of cultivating independent innovation enterprises and entrepreneurs, science and technology business incubator plays a vital role in decreasing the risk of entrepreneurship, promoting the incubation and industrialization of high-tech achievements. But a single incubator can't provide di- 
verse incubation resources, thus it should communicate and cooperate with others through networking. Incubators become the medium that connecting incubated enterprises and external environment, forming an incubation network in which the core is incubators and incubated enterprises, the auxiliary support is relevant external subjects such as universities, research institutions, intermediary institutions, investment and financing institutions.

By offering incubated enterprises and relevant external subjects a circumstance to build constant communication and cooperation [1], incubation network, which acts as a new kind of incubation system, can promote aggregation effect and platform effect, reduce the cost of resource communication [2], make up for the lack of start-ups' resources. Resource is the key factor which influences the formulation and implementation of innovation strategies, due to the primary stage of resource accumulation [3], incubated enterprises are faced with the plight of their own resources, it is necessary to make use of external cooperation relationship to obtain matching resources. Incubation network actively committed to fostering a lasting and stable cooperative relationship [4], establishes an integration platform of the external social capital for start-ups [5], by which forms an effective buffer against external uncertainty [6] [7]. Incubated enterprises share ideas and resources, promote the accumulation of cognitive social capital by communicating with other incubation subjects [8]. They could form social capital through incubation network, which helps to expand the scope and diversity of available resources, reduce the cost and risk of resource acquisition, and improve innovation performance.

According to the Resource Based Theory, the resource demand of incubated enterprises can be divided into two categories, that is tangible and intangible resources, in which the valuable, scarce and irreplaceable intangible resources are more important in the formation of the core competitiveness. Compared to tangible resources such as capital, equipment and factory, intangible resources have no obvious material carrier, mainly refer to technology, knowledge, information, ability and other elements which embedded in a series of products and services [9]. In the incubation network, whether start-ups could obtain the intangible resources through network cooperation and interaction or not is very important for them to improve innovation capability and innovation performance. Based on the background of incubation network, this paper studies the way enterprises obtain cognitive social capital through network embedding, break their own resource constraints, effectively access intangible resources in the environment of sharing sources and therefore enhance innovation performance. The conclusions will further expand the existing theory application situation of incubated enterprises' cognitive social capital and innovation performance.

\section{Literature Review}

\subsection{Cognitive Social Capital of Incubated Enterprises in Incubation Network}

Incubation network is a typical kind of network organization which consists all 
kinds of actors who have common development strategic objectives. Anne and Jones point out that the generalized incubation network including multiple incubators and actors [10]. A successful incubation network has four factors: diverse partners, third-party gatekeepers, financial leverage, and proactive partner engagement [11] [12]. This paper defines incubation network as a kind of organizational network which has the effect of resource sharing through close cooperation between incubators and other kinds of behavior nodes in the network [13].

Social capital is a series of actual and potential resources embedded in social networks, which can be contacted or acquired by individuals or social units [14]. In the incubation network, social capital of incubated enterprises comes from the cooperation relationship among different network subjects, these partnerships rely on shared perception to be strengthened. The role of incubator as a bridge provides effective protection to establish rich social relations for incubated enterprises, making them obtain policy support, financial support, professional consulting services, technical assistance and market information more easily [15]. The clustering advantage of network can help incubated enterprises and other network members forming the sharing of cognition, common values and vision, creating network synergies and enhancing the efficiency of shared resources [16]. The cognitive social capital of incubated enterprises in the incubation network refers to the common view of enterprise culture, entrepreneurial ideas and beliefs built through historical interactions among network subjects, it is a system containing expression, interpretation and meaning of common understanding among different network subjects which based on previous communication, shows as the approximate degree of vision and values.

\subsection{Acquisition of Intangible Resources of Incubated Enterprises in Incubation Network}

The incubated enterprises are faced with the initial lack of resources; they need to obtain resources from outside to make up for these deficiencies. Intangible resources are difficult to identify, the cost of being used or imitated by other competitors is high. Incubated enterprises should occupy intangible resources in time, and that can favor them to discover new opportunities in the innovative environment, help to identify and eliminate threats [17], bring a more sustainable competitive advantage. Incubation network broaden the channels for incubated enterprises to obtain intangible resources by providing business assistance (such as business planning, business relationships, financial services, employment and market management) and technical assistance (such as the contact, industry cooperation, technology transfer, intellectual property rights etc.) [18]. Valuable intangible resources often face transfer risk and high switching costs, incubation network promotes the formation of stable cooperative relations among network subjects, and increase their desire to share intangible resources, eliminate obstacles for incubated enterprises to obtain intangible resources, promote intangible resources to be shared and transferred [19]. 


\subsection{Innovation Performance of Incubated Enterprises}

At the early stage of incubation, the key point is how to establish the core products according to existed resources and market demand. Therefore, incubated enterprises' innovation performance mainly reflects the ability of product innovation, that is the ability which they use to follow market orientation, reallocate their own resources, apply new technology rationally, then launch more abundant or more functional products and services. The innovation ability of incubated enterprises is related to the development of new products, technology reform or transfer, which determines the products market development ability, cost level and technical level, and have a direct impact on innovation performance.

According to the main contents about product innovation ability of incubated enterprises, we select indexes to measure it from two aspects: innovation effect and innovation efficiency. Innovation effect studies the degree of innovation success of incubated enterprises, including the measurement of technology development, that is the number of patent technology, independent intellectual property rights, and the investigation of market sales, new product market share and product acceptance rate. Innovation efficiency is to examine input-output ratio in the process of enterprises' innovation, that is, whether the effort made for the success of innovation is effective or not, including conversion rate of scientific and technological achievements, rate of new product development and of success [20].

\section{Theoretical Framework and Research Hypothesis}

\subsection{Cognitive Social Capital and Innovation Performance of Incubated Enterprises in Incubation Network}

The cooperation relationship which based on the common understanding can promote network subjects to form complementary resource pattern, benefits from identifying and exchanging of resources that are proprietary, complex and non-encoding recessive, then improve the ability of innovation and cooperation.

Network subjects are under the guidance of incubators, they tolerate multi-culture to form a uniform network behavior standard and value criterion, further enhance network cohesion and the quality of innovation cooperation. The similar thought of different network subjects on the same situation means that they have no difficulty in understanding and communicating mutually, it is easy to identify partners' demands and give effective assistance, form the atmosphere helpful to the innovation and growth of incubated enterprises.

Shared vision reflects the willingness of different network subjects to share goals; it is a governance mechanism to reduce opportunism behavior. The innovation process is highly uncertain, and needs to be completed through continuous attempt. Consistent objectives help incubated enterprises to gather potential partners, avoid conflicts raised by goal divergence, to form collaborative innovation cooperation mode and share innovation risk and resources, work to- 
gether to improve innovation performance [21].

- Hypothesis 1 . The cognitive social capital has a significant positive effect on the innovation performance of incubated enterprises.

- Hypothesis 1a. Shared value has a significant positive effect on the innovation performance of incubated enterprises.

- Hypothesis 1b. Shared vision has a significant positive effect on the innovation performance of incubated enterprises.

\subsection{Acquisition of Incubated Enterprises' Cognitive Social Capital and Intangible Resources in Incubation Network}

Social capital promotes the ability of incubated enterprises to acquire intangible resources, they turn the simple relationship network into a rich network of resources with the accumulation of social capital, and the exchange and transformation of resources with other network subjects can improve their ability of recognition and acquisition of novel and scarce intangible resource [22].

The cognitive social capital provides incubated enterprises a tool to obtain intangible resources effectively. They need to strengthen the understanding of intangible resources by making use of common cognition, and then realize the effective digestion and absorption of intangible resources. It provides an opportunity for incubated enterprises to deepen cooperation with other subjects, helps effectively resolve conflicts of interests in the process of cooperation, create a harmonious atmosphere of cooperation, promote exchanges of intangible resources [23]. Same value increase the connectivity among network subjects, improve the transmission efficiency of intangible resources; the common vision makes them build the common goal, helps expanding the synergy effect and exploring the needs of intangible resources jointly [9].

- Hypothesis 2. The cognitive social capital has a significant positive effect on the acquisition of intangible resources of incubated enterprises.

- Hypothesis 2a. Shared value has a significant positive effect on the acquisition of intangible resources of incubated enterprises.

- Hypothesis 2b. Shared vision has a significant positive effect on the acquisition of intangible resources of incubated enterprises.

\subsection{Intangible Resource Acquisition of Incubated Enterprises and Innovation Performance}

Resource environment has a crucial impact on innovation performance. Innovation of incubated enterprises is the process of integrate existing resources and create core products, it requires not only the possession of tangible resources such as funds and goods, but also need to configure the intangible resources which formed from the effective configuration of technical and business support in the incubation network [24].

Incubated enterprises ought to maintain sensitivity to external information, explore new needs of customers from the market information, find a new breakthrough from technology information, obtain new trend from policy in- 
formation, access information in the incubation network and analyze them scientifically, accurately grasp innovation opportunity [25]. Innovation achievements will eventually face the market. Single start-up lacks reputation, confidence and attention from outside, thus its products are difficult to get admission in the market. The reputation advantage of the incubation network is beneficial for incubated enterprises. Through the network platform, they can display products effectively, and get wide recognition quickly, promote innovation achievements effectively [26].

Start-ups' own lack of knowledge accumulation need to be overcame by obtaining knowledge widely from the incubation network, breaking the barriers of technology innovation [27]. Incubated enterprises obtain management knowledge to realize the effective operation and efficient development of technology innovation; acquire marketing knowledge to realize the effective judgment of market and comprehend laws and regulations to ensure the legalization of enterprises' operation and technological innovation. Technology is the know-how and expertise needed in an industry, it is also the support for the success of incubated enterprises [28]. Technology existing in complex process can significantly improve the speed of product development, shorten the product update cycle. The innovation process is complex and changeable, incubated enterprises share the technology mutually through incubation network, which can effectively compensate for the lack of technology in the process of product development and achieve efficient innovation.

- Hypothesis 3. The acquisition of intangible resources has a significant positive effect on the innovation performance of incubated enterprises.

- Hypothesis 3a. The acquisition of intangible resources has a significant positive effect on the innovation effect of incubated enterprises.

- Hypothesis $3 \mathrm{~b}$. The acquisition of intangible resources has a significant positive effect on the innovation efficiency of incubated enterprises.

\subsection{The Mediating Role of Intangible Resources between Cognitive Social Capital and Innovation Performance}

Lack of intangible resources is the main obstacle to the innovation of start-ups [29]. Cognitive social capital helps incubated enterprises to enhance the understanding of their needs, promotes the integration efficiency of intangible resources. Incubated enterprises should search for matching intangible resources and digesting, absorbing them for their own use. The utilization efficiency of intangible resources can reflect their value and help to promote more innovation. Incubated enterprises accumulate cognitive social capital by making the relationship network evolving into a network of resource acquisition, thus obtaining intangible resources more efficiently for innovation and improving the innovation performance.

- Hypothesis 4. The acquisition of intangible resource plays an intermediary role in the impact of cognitive social capital on innovation performance.

Based on the above analysis, the theoretical model is shown in Figure 1. 


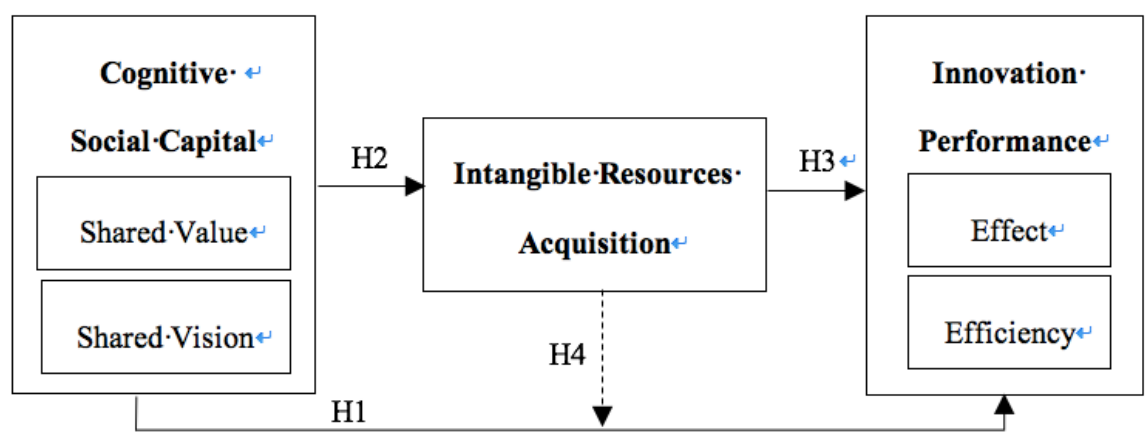

Figure 1. Theoretical model.

\subsection{Variable Measurement}

Based on the references, we designed the required items according to existing maturity indicators and scales. It mainly consists of two parts: the basic information of incubated enterprises and the influence of their cognitive social capital on intangible resource acquisition and innovation performance in the incubation network. Investigation of the influence is divided into: 1) cognitive social capital. Based on the research of Nahapiet, cognitive social capital contains 2 indicators: shared value and shared vision, and is measured by 8 items; 2) intangible resource acquisition. Based on the division of intangible resources by Danny [9], 5 items are selected to measure the acquisition of intangible resources of incubated enterprises; 3) innovation performance. Based on the research of Alegre J [20], innovation performance is measured by 2 indicators: innovation effect and efficiency, and the measurement items are 8. All indicators adopt 7 grade scoring method, of which " 1 " on behalf of totally disagree, "7" on behalf of totally agree.

\section{Research Conclusions and Prospects}

\subsection{Relevant Suggestions}

1) The incubated enterprises need to strengthen cognitive social capital accumulation through incubation network. They should make full use of the cohesion of incubation network, explore valuable innovation points from the frequent communication and interaction with other network subjects, and promote the formation of "sharing economy" model of innovation resources. As the core subjects, incubators should help network members establish shared perception, so that incubated enterprises can select partners and improve the effectiveness of cooperation.

2) Incubated enterprises should make efforts to strengthen the cognition, acquisition and utilization of intangible resources. They need to maintain a high degree of sensitivity to intangible resources in the incubation network, try to internalize external resources, absorb and digest intangible resources in time, so as to better serve innovation. In order to improve the acquisition efficiency of intangible resources, incubated enterprises should make full use of all kinds of resources platforms, such as investment and financing platform, business mentor platform, public service platform and technology platform. 


\subsection{Research Deficiency and Prospect}

This paper analyzes the static relationship among cognitive social capital, intangible resource acquisition and innovation performance. But the degree of social capital accumulation of incubated enterprises in the network is different according to incubation time. Their innovation process is also dynamic, and the demand for intangible resources is different according to different stages of innovation. Therefore, it is of great significance to further explore the relationship among the social capital of incubated enterprises, intangible resources demand and innovation performance in dynamic evolution process. These issues will be the focus of future research.

\section{Acknowledgements}

Supported by the National Nature Science Foundation of China (Grant No. 71403182). Zhenhua $\mathrm{Li}$ and Fuwei Li would like to extend our sincere gratitude to the sponsor of the national conference, for it provides a valuable chance for scholars to communicate in their research area. Second, grateful acknowledge to our research group, both professors and graduate students gave us considerable help by means of suggestion and comments.

\section{Supported}

This work was supported by the National Nature Science Foundation of China (NSFC) [grant number 71403182].

\section{References}

[1] Li, Z-H. and Zhao, L-M. (2014) The Characteristic and Dynamic Capability Development of Regional Technology Incubation Networks Based on Polycentric Governance. Science Management Research, 6, 77-83.

[2] Peters, L., Rice, M. and Sundararajan M. (2004) The Role of Incubators in the Entrepreneurial Process. The Journal of Technology Transfer, 29, 83-91. https://doi.org/10.1023/B:JOTT.0000011182.82350.df

[3] Zhang, B-J., Hu, H-Q. and Zhang, D-H. (2011) A Literature Review of Networking Mechanism about the Business Incubators. Science of Science and Management of S.\& T, 32, 152-157.

[4] Zhang, L., Qi, R-Q. and Zhou, Y-T. (2014) Determinants of Tenants Successful Graduation: Research Based on the Perspective of Co-Production Theory. Studies in Science of Science, 32, 758-766.

[5] Bruneel, J., Ratinho, T. and Clarysse, B. (2012) The Evolution of Business Incubators: Comparing Demand and Supply of Business Incubation Services across Different Incubator Generations. Technovation, 32, 110-121. https://doi.org/10.1016/j.technovation.2011.11.003

[6] Wang, G-H., Zhou, J-L. and Xing, R. (2015) Study on Object Selection Strategy of Knowledge Distribution in Innovation Incubation Network Based the Process of Knowledge Dual-Distribution. Science of Science and Management of S.\& T, 36, 105-114.

[7] Zhang, H-J. and Tan, J-S. (2014) Alliance Network and Enterprise Innovation Per- 
formance: A Cross Level Analysis. Managment World, 3, 163-169.

[8] Dodd, S.D. and Patra, E. (2002) National Differences in Entrepreneurial Networking. Entrepreneurship\& Regional Development, 14, 117-134.

https://doi.org/10.1080/08985620110111304

[9] Soetanto, D.P. and Jack, S.L.(2013) Business Incubators and the Networks of Technology-Based Firms. The Journal of Technology Transfer, 38, 432-453. https://doi.org/10.1007/s10961-011-9237-4

[10] Bollingtoee, A. and Pulhoi, J. (2005) The Networked Business Incubator: Leveraging Agency. Journal of Business Venturing, 20, 265-290.

https://doi.org/10.1016/j.jbusvent.2003.12.005

[11] Pittaway, L., Robertson, M. and Munir, K. (2004) Networking and Innovation: A Systematic Review of the Evidence. International Journal of Management Reviews, 5, 137-168. https://doi.org/10.1111/j.1460-8545.2004.00101.x

[12] Leven, P., Holmstrom, J. and Mathiassen, L. (2014) Managing Research and Innovation Networks: Evidence from a Government Sponsored Cross-Industry Program. Research Policy, 43, 156-168. https://doi.org/10.1016/j.respol.2013.08.004

[13] Ratinho, T. and Henriques, E. (2010) The Role of Science Parks and Business Incubators in Converging Countries: Evidence from Portugal. Technovation, 4, 278-290. https://doi.org/10.1016/j.technovation.2009.09.002

[14] Putnam, R.D. (1995) Bowling Alone: America's Declining Social Capital. Journal of Democracy, 6, 65-78. https://doi.org/10.1353/jod.1995.0002

[15] Battisti, M. and McAdam, M. (2012) Challenges of Social Capital Development in the University Science Incubator the Case of the Graduate Entrepreneur. The International Journal of Entrepreneurship and Innovation, 13, 261-276. https://doi.org/10.5367/ijei.2012.0091

[16] Yu, S-H. (2013) Social Capital, Absorptive Capability, and Firm Innovation. Technological Forecasting and Social Change, 80, 1261-1270. https://doi.org/10.1016/j.techfore.2012.12.005

[17] Shao, X-D. and Meng, X-Z. (2015) Study on the Relations between Strategic Social Responsibility Behavior and Corporate Sustainable Competitive Advantage Sources from the Resource-Based Theory. J. Economy Management, 37, 56-65.

[18] Scillitoe, J.L. and Chakrabarti, A.K. (2010) The Role of Incubator Interactions in Assisting New Ventures. Technovation, 30, 155-167. https://doi.org/10.1016/j.technovation.2009.12.002

[19] BarNir, A. and Smith, K.A. (2002) Interfirm Alliances in the Small Business: The Role of Social Networks. Journal of Small Business management, 40, 219-232. https://doi.org/10.1111/1540-627X.00052

[20] Alegre, J., Lapiedra, R. and Chiva, R. (2006) A Measurement Scale for Product Innovation Performance. European Journal of Innovation Management, 9, 333-346. https://doi.org/10.1108/14601060610707812

[21] Wang, G-H., Zhou, J-L. and Tang, Y-L. (2014) The Model and Simulation for Knowledge Transfer among Innovation Incubation Network Based on Small World Effect. Science of Science and Management of S.\& T, 35, 53-63.

[22] Patton, D. (2014) Realising Potential: The Impact of Business Incubation on the Absorptive Capacity of New Technology-Based Firms. International Small Business Journal, 32, 897-917. https://doi.org/10.1177/0266242613482134

[23] Li, H-C. and Chen, X-J. (2015) Research on the Influence Mechanism of Social Capital on Enterprise Technology Innovation. Science and Technology Manage- 
ment Research, 35, 80-84.

[24] Borg, E.A. (2001) Knowledge, Information and Intellectual Property: Implications for Marketing Relationships. Technovation, 21, 515-524.

https://doi.org/10.1016/S0166-4972(00)00066-3

[25] McAdam, M. and Marlow, S. (2009) A Preliminary Investigation into Networking Activities within the University Incubator. International Journal of Entrepreneurial Behavior \& Research, 14, 219-241. https://doi.org/10.1108/13552550810887390

[26] Filieri, R. and Alguezaui, S. (2014) Structural Social Capital and Innovation. Is Knowledge Transfer the Missing Link? Journal of Knowledge Management, 18, 728-757. https://doi.org/10.1108/JKM-08-2013-0329

[27] Kirkbesoglu, E. (2013) The Impact of Social Capital on Managerial Reputation. Procedia-Social and Behavioral Sciences, 99, 439-445. https://doi.org/10.1016/j.sbspro.2013.10.512

[28] Wang, G-H., Zhou, J-L. and Xing, R. (2015) Research on the Relationship among Social Capital, Joint Value Creation and Innovation Incubation Performance. Forecasting, 34, 34-39.

[29] Yoon, H., Yun, S. and Lee, J. (2015) Entrepreneurship in East Asian Regional Innovation Systems: Role of Social Capital. Technological Forecasting and Social Change, 100, 83-95. https://doi.org/10.1016/j.techfore.2015.06.028 